\title{
Solute Carrier Family 2, Facilitated Glucose Transporter Member 3
}

National Cancer Institute

\section{Source}

National Cancer Institute. Solute Carrier Family 2, Facilitated Glucose Transporter

Member 3. NCI Thesaurus. Code C115022.

Solute carrier family 2, facilitated glucose transporter member 3 (496 aa, $\sim 54 \mathrm{kDa}$ ) is encoded by the human SLC2A3 gene. This protein plays a role in the transport of glucose. 